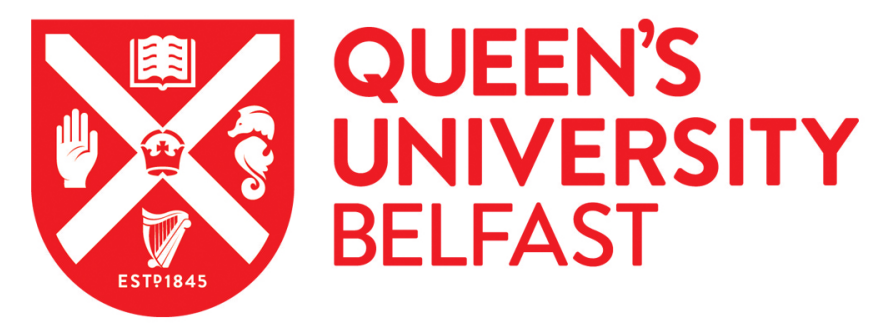

\title{
Assessing differences in levels of food trust between European countries
}

Murphy, B., Benson, T., Lavelle, F., Elliott, C., \& Dean, M. (2021). Assessing differences in levels of food trust between European countries. Food Control, 120, [107561]. https://doi.org/10.1016/j.foodcont.2020.107561

\author{
Published in: \\ Food Control
}

Document Version:

Peer reviewed version

Queen's University Belfast - Research Portal:

Link to publication record in Queen's University Belfast Research Portal

Publisher rights

(c) 2020 Elsevier Ltd.

This manuscript is distributed under a Creative Commons Attribution-NonCommercial-NoDerivs License

(https://creativecommons.org/licenses/by-nc-nd/4.0/), which permits distribution and reproduction for non-commercial purposes, provided the author and source are cited.

\section{General rights}

Copyright for the publications made accessible via the Queen's University Belfast Research Portal is retained by the author(s) and / or other copyright owners and it is a condition of accessing these publications that users recognise and abide by the legal requirements associated with these rights.

Take down policy

The Research Portal is Queen's institutional repository that provides access to Queen's research output. Every effort has been made to ensure that content in the Research Portal does not infringe any person's rights, or applicable UK laws. If you discover content in the Research Portal that you believe breaches copyright or violates any law, please contact openaccess@qub.ac.uk. 
4 Blain Murphy ${ }^{a}$, Tony Benson ${ }^{a}$, Fiona Lavelle ${ }^{a}$, Chris Elliott ${ }^{a} \&$ Moira Dean $^{a}$

\section{Countries.}

anstitute for Global Food Security (IGFS), School of Biological Sciences, Queen's University Belfast, United Kingdom.

Corresponding Author:

Prof. Moira Dean.

Institute for Global Food Security (IGFS), Biological Sciences, Queen's University Belfast, 19 Chlorine Gardens, BT9 5DL, United Kingdom.

\section{Email: Moira.dean@qub.ac.uk}

\section{Highlights}

- Consumer trust in food differs significantly between countries.

- High consumer trust does not relate to low distrust, in relation to food.

- Countries exhibit similar consumer trust and distrust across the constructs.

\section{Abstract}

\section{Introduction}

As the globalisation of the food market continues, consumer trust in the food supply chain and the related actors are vital for the functioning of the food industry. While past research has primarily focused on consumer trust within countries and how it can be increased, studies on cross country differences and the comparison between trust and distrust are limited to review articles. To address this gap, this study investigates the levels of trust and distrust in food products and organisations across four European countries (Finland, Germany, Greece and the UK).

\section{Methods}

Using a previously validated consumer Trust Toolkit (Benson et al., 2020), an online cross-sectional survey explored consumer's trust in food and in food supply chain actors. In addition to this toolkit measuring trust and distrust constructs, the questionnaire for the current study also included relevant sociodemographic,

\section{Assessing differences in levels of food trust between European}


32 household, and psychological items. The data was analysed using ANOVAs,

33 descriptive statistics and regressions using SPSS v26.

\section{Results}

35 Overall, consumers $(n=1027)$ had a high level of trust in an EU food product (beef

36

37

38

39

40

41

42

43

44

45

46

47

48

49

50

52 burgers; mean=3.981; $S D=1.353$ ) and the organisations involved in creating and certifying the product (organisations; mean $=4.263 \mathrm{SD}=1.129$, food chain; mean=4.434, SD=1.177). The data found that Finnish and UK consumers had the highest levels of trust overall, while German and Greek consumers had lower trust in their food and food-related organisations. Interestingly, Finnish consumers reported the highest levels of distrust in food-related organisations, which indicates that foodrelated distrust is more nuanced than simply being the opposite of food-related trust. These findings are discussed in relation to the cultural context of each country and risk practises.

\section{Conclusions}

The levels of food trust and distrust differs across countries highlighting the need for developing different business and organisational strategies to market products in different countries/cultures. Understanding consumers' trust in food and in foodrelated organisations is the first step in benchmarking and improving consumer trust across Europe.

Word Count Abstract: 311

Keywords:

Trust, Distrust, Food, Consumer, Country differences

\subsection{Introduction}

As the globalisation of the food market continues, consumer trust in the food supply chain and in food supply chain actors are vital to the functioning of the food industry (Houghton et al., 2006). Consumer trust in a product's sourcing, processing and retailing is a key predictor of purchasing intentions and behaviour (Hong \& Cha, 2013; Hong \& Cho, 2011). As consumer systems and production are complex, with many stages undertaken between producers and consumers, which are 'invisible' to consumers, the measurement of levels of trust relating to different trust types are required (Coveney et al., 2015). In our previous work (Benson et al., 2020), four types of trust were identified; general (interpersonal) trust, trust in food chain actors, trust in organisations and trust in food products. Two types of distrust (general and organisational) were also identified. How these trust/distrust types differ across countries form the basis of this article. 
While past research has primarily focused on consumer trust within countries and how it can be increased, some reviews have highlighted country differences in trust; advocating the need for better communication with the public and the need for consumer research across different cultural contexts (Aertsens et al., 2009; Kendall et al., 2019). We focused on countries who were regulated in food safety directives within the EU (Bondoc, 2016a; Bondoc, 2016b). Thus, four countries (Finland, Germany, Greece and the UK) who have different experiences with food scandals were chosen to be examined in the current study.

\subsection{Choice of countries for comparison}

The UK and Germany are large, well-researched European food economies, which have experienced significant food safety scandals over the last 30 years. The Bovine Spongiform Encephalopathy (BSE) outbreak in the 1990s (Smith et al., 2007) and the 'horsemeat scandal' (Tse et al., 2016), led to reduced sales of affected products (Halkier et al., 2007). Unsafe and inauthentic food can lead to an increase in distrust in the food system. Food manufacturers, the media and specific marketing techniques have been linked to previous food safety scandals and viewed as distrustful institutions (Dolgopolova et al., 2015; Poppe \& Kjærnes, 2003). In comparison, both Finland and Greece have not experienced large-scale food safety scandals that affected food sales. Finland and Greece are also smaller understudied food economies, based in Scandinavia and the Mediterranean, which are important comparators in international trust research. These regions also differ significantly in their levels of consumer (general) trust and cultural norms (Kjærnes, 2006).

\subsection{Trust constructs (General, organisational, chain and product)}

General Trust is a measure of how trusting an individual is in general as a person (Stefani et al., 2008). Within general trust, Germany is typically regarded as a 'lower trust economy', an exception amongst both central European countries and highly developed markets (Fritz \& Fischer, 2007; Peters et al., 2007; Poppe \& Kjærnes, 2003). Similarly, the UK and Greece have low levels of general trust (Edelman, 2018; Ervasti et al., 2019; European Food Safety Authority., 2010). The economic difficulties experienced in Greece during their "bail-out crisis" (2010-2018) was shown to have an insignificant effect on their long-term general trust (Ervasti et al., 2019). Finland historically has high levels of trust between individuals (Wiseman \& Popov, 2015). Therefore, we anticipate these trust levels to be reflected in the general trust measure from the four countries in this survey.

Organisational trust is how much an individual trusts an organisation which oversees a part of the food chain (but is not necessarily part of the food chain). e.g. Food safety authority. Finland has a reputation for strong food safety regulation 
106

107

108

109

110

111

112

113

114

115

116

117

118

119

120

121

122

123

124

125

126

127

128

129

130

131

132

133

134

135

136

137

138

139

140

141

142

143

organisations, especially in locally produced products; which are highly trusted by their consumers (Finnish Food Safety Authority, 2018; Järvelä et al., 2006; Poppe \& Kjærnes, 2003). Greek consumers have been found to have low levels of awareness about quality certification of food products and the organisations involved in this (Botonaki et al., 2006). UK respondents rated governmental organisations and scientists (in universities rather than in industry) as the most trustworthy organisations; ranking the food industry the lowest in trustworthiness (Houghton et al., 2006)

Food chain trust refers to how much an individual trusts the actors or organisations involved in food production; such as farmers. Greek consumers had been identified as having high levels of concern for food production and quality (European Commission., 2012); which may be linked to significant political and economic turmoil lowering organisational/impartial institutional trust (Ervasti et al., 2019). Similarly, German consumers have reported low trust in food manufacturers (Dolgopolova et al., 2015) with marketing techniques by food manufacturers highlighted as a specific concern (Dolgopolova et al., 2015). UK consumers have high levels of trust in food chain actors, such as farmers but this was linked to the belief that the produce was "local" i.e. British (Duffy et al., 2005). Finland's research on food chain actor trust is under-developed and focuses predominantly on trust and beliefs relating to organic food rather than the actors (Nuutila \& Kurppa, 2017). Therefore, food chain trust needs further investigation.

Product trust is how much an individual trusts a specific product (in this instance, EU beef burgers). UK respondents have high trust in their beef products, with $47 \%$ of UK respondents believing beef to be "very safe" to eat, the highest measured in seven European countries (overall mean 29\%) (Poppe \& Kjærnes, 2003). One reason for this high trust may be that most beef consumed in the UK is from the UK (81\%) (National Beef Association (UK), 2015). In comparison, German respondents had the lowest levels of believing their beef to be "very safe" (18\%) (Poppe \& Kjærnes, 2003). In Berg et al' study (2005), over two-thirds of Danish and Norwegian respondents had high trust in the safety of beef, even amidst a foot and mouth crisis. This indicates Scandinavian countries have high trust in beef, which may correspond to Finland within this survey. Greek trust in beef products has been under-researched, but improved traceability of meat products (especially for brand-names) encouraged an increased willingness to pay among Greek consumers (Kehagia et al., 2007).

It is important to note that the timing of the survey was such that, Brexit and its implication for food supplies and regulation in the UK could be a confounding factor which need to be taken into account when comparing UK consumers with the other EU countries and their trust profiles (Matthews, 2016). 


\subsection{Differences in Trust and Distrust}

Trust is a diffuse and complex concept which has been measured across many disciplines. Many dictionaries imply distrust to be an opposite concept of trust; with distrust to be "no trust in" (verb) and a "lack of trust; doubt; suspicion" (Flexner $\&$ Hauck, 1993) describing trust/distrust as opposite sides of the same coin (Harrison McKnight \& Chervany, 2001). The most relevant and cited definition of trust is that it is "the willingness of a party to be vulnerable to the actions of another party based on the expectation that the other will perform a particular action important to the trustor, irrespective of the ability to monitor or control that other party" (Mayer et al., 1995). In comparison, distrust is believed to be associated with different emotions than trust; such as the survival instinct and protection from harm (Harrison McKnight et al., 2002; Harrison McKnight \& Chervany, 2001) and has a greater effect on highrisk behaviours and choices (Harrison McKnight et al., 2002). Assessing both constructs as distinct constructs and measuring them separately is vital to accurately represent the differences in motivations (willingness to be vulnerable in trust: the survival instinct in distrust) influencing consumers' behaviours (Cho, 2006; Dietz \& Den Hartog, 2006).

\subsection{Aims}

This study aims to; identify and understand differences in trust and distrust across different European countries. In addition, the study investigates the relationship between trust and distrust in relation to food.

\subsection{Hypotheses}

$\mathrm{H} 1$ : Levels of consumer trust in the different constructs (general trust, organisational trust, food chain actor trust and product trust) will be significantly different across the countries.

$\mathrm{H} 2$ : Levels of consumer trust and consumer distrust will be significantly different.

H3: The consumer trust in a food product (e.g. EU beef burgers) will be significantly correlated with their level of general trust, their organisational trust and their level of trust in the involved food chain actors.

\subsection{Materials and Methods}

\subsection{Design}

An online survey was conducted using the previously developed and validated trust toolkit (Benson et al., 2020). In addition to this toolkit measuring trust and distrust constructs, the questionnaire for the current study also included relevant sociodemographic (e.g. What is your current occupation status?), household (e.g. Are 
181

182

183

184

185

186

187

188

189

190

191

192

193

194

195

196

197

198

199

200

201

202

203

204

205

206

207

208

209

210

211

212

213

214

215

216

217

218

you responsible for the food and grocery shopping in your household?), and psychological items such as the level of risk perceived by the participant within their society (e.g. Economic crises like recession).

Six trust and distrust constructs were assessed in total. Each item was rated on 7point semantic-differential scales ranging from 'strongly disagree' (1) to 'strongly agree' (7). These scales were scored to indicate higher levels of trust and distrust from higher scores. For three constructs, specific organisations and products were used (Organisational trust \& distrust (European Food Safety Authority (EFSA)); Product trust (EU beef burgers). A full list of questions can be found within Benson et al, (2020) (Table 4). Specifically, the types of trust and distrust examined were:

- General trust. Trust at the individual level. How trusting an individual is in general as a person. Total of five items such as 'Most people are basically honest.

- Organisational trust. How much an individual trusts an organisation which oversees a part of the food chain (but is not necessarily part of the food chain). Total of seven items, such as 'EFSA has practices that favour the consumer's best interests'

- Food chain trust. How much an individual trusts the actors or organisations involved in food production. A total of 17 items, such as 'Food manufacturers are honest about the safety of food'.

- Product trust. How much an individual trusts a product (in this instance, EU beef burgers). EU beef burgers were chosen as they are a product which has been involved in previous food scandals in the EU and is commonly consumed throughout the relevant countries. A total of 10 items, such as "I trust that EU beef burgers are authentic.'

- General distrust. Distrust at the individual level. How distrusting an individual is in general as a person. A total of four items, such as '/ never rely on other people'.

- Organisational distrust. How much an individual distrusts an organisation. A total of three items, such as 'Information from EFSA is distorted'.

To further inform the model, other measures including an adapted version of the risk perception scale (Siegrist et al., 2005) - which measured how risky participants considered hazards to be (range 1-5) and how this influences a person's decisions and behaviour was added. Individuals were asked to what extent they were interested in seeking food safety risk information if new risks to food safety were discovered (adapted from (Etienne et al., 2018)). Participants were asked to select types of information, such as 'general description of the risk' and 'technical or scientific details', which was used as a score (range $0-7$ ) to indicate individual's 
219

220

221

222

223

224

225

226

227

228

229

230

231

232

233

234

235

236

237

238

239

240

interest in seeking food safety information, with higher scores indicating higher interest.

Reporting was guided by the STROBE criteria (Vandenbroucke et al., 2014). Ethical approval was granted by the Queen's University Belfast School of Biological Sciences Research Ethics Committee.

\subsection{Sampling}

Individuals were invited to participate in the survey by a research agency (Dynata) from their online panel on their platform of consumers in Finland, Germany, Greece and the UK in 2018. Individuals were paid a small fee to complete the survey. Individuals completed a series of screening questions to assess their eligibility to take part in the study, which took approximately 20 minutes to complete. To reduce bias, anyone aged under 18 or working in (or living in a household with anyone working in) food safety, food processing or manufacturing as well as the farming, growing, wholesale or retail of food or drinks were excluded.

A statistical power analysis using G-Power calculations (Faul et al., 2007) was performed for sample size estimation, comparing trust and distrust profiles between countries; able to detect small effect sizes (0.25: (Cohen, 1988). With an alpha $=.05$ and power $=0.80$, the projected sample size needed with this effect size (Faul et al., 2007) was $n=253$ per group. Therefore, the sample size of 1027 was suitably powered for the analysis conducted.

\subsection{Data analysis}

Data analysis was conducted using IBM SPSS Statistics V25. As a forced response option was used in the survey, no data was missing. Descriptive statistics were used to explore the individual level data. Groups were compared using T-tests and $\mathrm{Chi}^{2}$ tests. Between-country differences were assessed using Analysis of Variance (ANOVAs) with bonferroni post-hoc tests. Pearson's correlations were used to assess relationships between the trust constructs. Finally, to understand the most important influences on product trust, hierarchical multiple regressions were conducted. All analysis was considered significant at a level of 0.05 .

\subsection{Results}

\subsection{Participants}

In total, 1,027 individuals participated; representative (approximately) in terms of gender, age and region (maximum $\pm 8 \%$ difference between population figures and sample achieved). Of the 1,027 respondents, the majority were female (53\%), had a 
mean age of $46.99(S D=16.95$, range $=18$ to 85$)$ and were split equally over the 4 countries $(U K=256$; Germany $=257$; Finland $=253$, Greece $=253)$, $($ Table 1$)$.

Participants were similar in profile across countries except on educational attainment $(p<0.001)$. Greek respondents were most likely to be university educated $(60.2 \%)$, while university-level attainment was lower in German (22.2\%) and Finnish (23.4\%) participants.

\section{Insert Table 1 here}

There were significant differences between countries across all four trust constructs $(p<0.001)$. Therefore, hypothesis 1 was supported (Figure 1). Germany and Greece consistently had lower general, food chain and product trust than Finland and the UK; while Germany had the lowest organisational trust, (Table 2, Figure 1).

Hypothesis 2 was supported as the two distrust constructs differed significantly across countries $(p<0.001)$, Figure 1. Finland reported the highest levels of organisational and general distrust across countries, while Greece had the lowest levels of general distrust. There were no differences in organisational distrust between Germany, Greece and the UK. There was a similar dispersion to general and organisational trusts in Finland with both trust and distrust types being high.

Insert Table 2 and Figure 1 here

As expected, chain, organisation and general trusts were significantly correlated with product trust $(r=0.561, P<0.001 ; r=0.499, P<0.001 ; r=0.321, P<.001$ respectively), Table 3. Therefore hypothesis 3 was supported.

A hierarchical multiple regression analysis showed the relationship between sociodemographic, trust and distrust variables and product trust (EU beef burgers), Table 4. In the baseline model sociodemographic factors, accounted for $1.9 \%$ of the variance in product trust, with a significant independent contribution $(P<.001)$. The addition of the trust and distrust variables to the final model, explained a further $40.3 \%$ ( $42.2 \%$ overall) of the variance $(P<.001)$. The variables contributing most significantly to explain the variance in the final model included chain trust, organisational trust and age (Table 3). 
288 Subgroup analysis showed that age-grouping was significant for 3 trust constructs 289 (General $(p<0.001)$, chain $(p=0.045)$ and product $(p<0.012)$ trusts). Younger 290 participants (<34 years-old) had higher levels of product trust, while general trust 291 increased as respondents age increased. Chain trust was complicated with 18-25 and 292 over 65-year-olds being more likely to have higher chain trust, while 35-54-year-olds 293 had lower chain trust. This change occurred in the 24-34-year-old age group, which 294 was split evenly.

295 There were significant cultural differences between countries in risk perception $296(p<0.001)$ and information sources sought $(p=0.028)$, Table 2 (Secondary findings). 297 Greek respondents had the highest perception of risk in their general lives, while all 298 countries desired approximately 3.5 information sources, although those in the UK 299 sought the most number of sources for information $(p=0.028)$. 


\subsection{Discussion}

To the best of our knowledge, this is the first study to use a validated trust toolkit (Benson et al., 2020) to show how the norms and cultural context of different countries affect the different constructs of consumer trust (chain, general, organisational and product trust). Finnish and UK respondents reported higher levels of trust across the trust/distrust constructs than German and Greek respondents. Overall, Finnish respondents also reported the highest levels of general and organisational distrust, which were previously validated as separate constructs (Benson et al., 2020). Our findings further strengthen the standing of trust and distrust as separate constructs. We discuss how these findings may have been influenced by national issues and how it can be used.

Our finding of higher consumer trust in Finland and the UK is generally in line with previous research (Aertsens et al., 2009; Järvelä et al., 2006; Poppe \& Kjærnes, 2003). However, the UK's high scores in general trust and chain trust are higher than those reported in the previous research (Edelman, 2018; European Food Safety Authority., 2010). Similarly, in Germany and Greece the general level of trust is low (Dolgopolova et al., 2015; Ervasti et al., 2019; European Commission., 2012; Fritz \& Fischer, 2007; Peters et al., 2007; Poppe \& Kjærnes, 2003). This implies that, in these countries, individuals have low levels of trust in each other.

Within the sample, there was no effect of gender on the trust constructs, despite males usually shown to exhibiting a more trusting attitude towards food (Berg, 2004; Kjærnes, 2006; Poppe \& Kjærnes, 2003). General trust in others increased as respondents aged, reflecting what has been shown in large international studies (Li \& Fung, 2013). However most of the trust studies have been cross-sectional data, which are prone to differences in cohorts/generations, rather than longitudinal studies showing that trust increases as one ages (Li \& Fung, 2013).

Previous food safety crises in the UK and Germany, have shown minimal effects on consumer trust (Poppe \& Kjærnes, 2003; Wales et al., 2006). One theory is that these consumers have been "desensitised" (Ding et al., 2013) to food scandals, as Germany has experienced over 25 noticeable food contamination incidents since 2000 (Rieger et al., 2016). These multiple incidents may be linked to the lower trust across the trust constructs in Germany. In comparison, the consequences of food safety crises, such as increased regulation and technological sophistication, have been linked to strengthening long-term consumer trust; especially produce from perceived "high competence countries", such as Germany and Ireland (Barbarossa et al., 2016). This may explain why countries who have undertaken public enquires into food safety, such as the Elliott review (UK) (Elliott, 2014) has increased trust over time in previously lower trust countries. 
At an organisational trust level, there were high levels of trust in the statutory body, the EFSA in all the countries except Germany. Higher organisational trust has been shown to moderate the 'scare' impact of food crises, especially amongst highly educated groups (Lobb et al., 2007). The German sample was less likely to have a university-level qualification, which may be a contributing factor in explaining why their trust in organisations was lower than the other included countries.

Within the UK sample, there was high trust in the EFSA, even with the advent of Brexit. The UK regulations have provisioned for the transfer of EFSA responsibilities for food safety to the Food Standards Agency (Chartered Institute of Environmental Health, 2019); and future research within the UK should explore how organisational trust changes after the transfer of responsibilities and if there is a change after the transfer of responsibilities. However, this is dependent on future Brexit negotiations.

Further, trust in the food chain (food manufacturers) is probably the most important predictor of consumer confidence in the safety of food products (de Jonge et al., 2008). In the correlation model (Table 3), trust in the chain was the highest predictor of trust in the product. Despite food labelling approaches being described as "disparate and non-cohesive" (Tonkin et al., 2015), food labelling has the capacity to improve trust in food chain actors (such as food manufacturers).

Several other factors have previously been identified as important in building foodrelated trust; communication of information and appreciation of potential risks. For communication, respondents sought 3.5 sources of information on average about food, with UK respondents seeking the most sources and German respondents the least. Previous research identified German consumers were less likely to rely on the media for their information than other countries: suggesting that information in Germany should be disseminated via research or medical organisations/professionals (Dolgopolova et al., 2015). Information from the media consistently amplifies the negative effects affecting the likelihood to purchase (Lobb et al., 2007). The media coverage of the health safety risks of food-related scandals had a significantly negative influence on affected meat product consumption (Rieger et al., 2016). The importance of clear, independent and trustworthy information sources for food scares has been raised previously within the Elliott report (Elliott, 2014), and is supported by our findings. Overall, the low levels of trust reported by German and Greek respondents' highlights the need for greater consumer-trust building in these countries; which is challenging in countries with sceptical consumers (Van Kleef et al., 2007).

In relation to trust and distrust as concepts in relation to food, we showed that they are different constructs as trust is not always correlated to lower distrust; as found in Finland and Greece. One of the key issues that may explain this lack of correlation 
between countries trust and distrust may be, the presence of governmental/authorised bodies (outside of industry), which "oversee" food quality. These bodies have been linked to decreases in food distrust through the reduction of vulnerabilities through strong legislation and vigilance (Ekici, 2004; Wideback, 2011). A lack of such bodies can decrease the protection consumers feel they have; a key ingredient in increasing distrust (Harrison McKnight et al., 2002; Harrison McKnight \& Chervany, 2001). Industry/"big business" being perceived as influencing food safety protection was identified by US consumers as a main source of distrust in food (Ekici, 2004).

Perception of risk in food safety has previously been highlighted as a factor in national-specific differences between countries (Van Kleef et al., 2007). In some countries, such as Greece, their previous experience of poor reactive risk management, in incidents such as mould contaminated honey, may be linked to their high-risk perception in this study (Van Kleef et al., 2007).

The results further indicate that the interventions to improve food trust across countries should be aware that consumers in different countries have different baseline levels of trust, distrust and risk perception. Interventions should be tailored to each country as countries (such as Finland and Germany) have vastly different profiles across the trust constructs.

\section{Strengths and limitations} The trust toolkit (Benson et al., 2020) has been validated across multiple countries, showing broad application and has been assessed for multiple types of validity and reliability. It has also been shown to be consistent across 4 languages. By using the validated toolkit in the current study, this research can be confident in the crosscultural findings. The use of a relatively large overall sample size (approximately representative of each country) was a further strength of the current study, with findings adequately powered. However, the use of a cross-sectional method limits the ability to track changes in trust or pinpoint cause and effect relationships. In addition, the inclusion of four European countries limits the study in its applicability outside of Europe, especially in the east (Krockow et al., 2017; Yamagishi \& Yamagishi, 1994).

Future research should expand this work by comparing other markets and countries to identify trust differences; especially in Asia, where attitudes to trust in food may differ from European markets (Krockow et al., 2017; Yamagishi \& Yamagishi, 1994). Future research applying the items to different examples e.g. products or organisations would also show validity and reliability in different cultural contexts. 
415 Conclusion

416 In conclusion, the consumer trust toolkit highlighted differences in food trust and

417 distrust between countries; specifically, consumer trust in Finland and the UK being

418 higher compared to the consumer trust in Germany and Greece. Further,

419 disentangling of trust and distrust in relation to food has shown that trust profiles

420 differ across countries; with high trust in food not correlating with low distrust,

421 indicating that trust and distrust are different constructs.

422

$423 \quad$ Funding

424 This work was supported by EIT Food, the innovation community on Food of the

425 European 609 Institute of Innovation and Technology, a body of the European Union,

426 under Horizon 2020, 610 the EU Framework Programme for Research and Innovation

427 [grant number 18021].

428

429 Declaration of competing interest

430 None.

431

432

433

434

435

436

437

438

439

440

441

442

443 
444

445

446

447

448

449

450

451

452

453

454

455

456

457

458

459

460

461

462

463

464

465

466

467

468

469

470

471

472

473

474

475

476

477

478

479

480

481

\section{References}

Aertsens, J., Verbeke, W., Mondelaers, K., \& van Huylenbroeck, G. (2009). Personal determinants of organic food consumption: A review. Br Food J., 111(10), 11401167. https://doi.org/10.1108/00070700910992961

Barbarossa, C., De Pelsmacker, P., Moons, I., \& Marcati, A. (2016). The influence of country-of-origin stereotypes on consumer responses to food safety scandals: The case of the horsemeat adulteration. Food Quality and Preference, 53, 71-83. https://doi.org/10.1016/j.foodqual.2016.05.015

Benson, T., Lavelle, F., Spence, M., Elliott, C. T., \& Dean, M. (2020). The development and validation of a toolkit to measure consumer trust in food. Food Control, 110. https://doi.org/10.1016/j.foodcont.2019.106988

Berg, L. (2004). Trust in food in the age of mad cow disease: A comparative study of consumers' evaluation of food safety in Belgium, Britain and Norway. Appetite, 42(1), 21-32. https://doi.org/10.1016/S0195-6663(03)00112-0

Berg, L., Kjaernes, U., Ganskau, E., Minina, V., Voltchkova, L., Halkier, B., \& Holm, L. (2005). Trust in food safety in Russia, Denmark and Norway. Eur Soc 7(1), 103129. https://doi.org/10.1080/1461669042000327045

Botonaki, A., Polymeros, K., Tsakiridou, E., \& Mattas, K. (2006). The role of food quality certification on consumers' food choices. Br Food J, 108(2), 77-90. https://doi.org/10.1108/00070700610644906

Bondoc I. (2016a). European Regulation in the Veterinary Sanitary and Food Safety Area, a Component of the European Policies on the Safety of Food Products and the Protection of Consumer Interests: A 2007 Retrospective. Part One: the Role of European Institutions in Laying Down and Passing Laws Specific to the Veterinary Sanitary and Food Safety Area. Universul Juridic, Supliment, pp. 12-15 (Retrieved from http://revista.universuljuridic.ro/supliment/european-regulation-veterinarysanitary-food-safety-area-component-european-policies-safety-food-productsprotection-consumer-interests-2007-retrospective/).

Bondoc I. (2016b). European Regulation in the Veterinary Sanitary and Food Safety Area, a Component of the European Policies on the Safety of Food Products and the Protection of Consumer Interests: A 2007 Retrospective. Part Four: Decisions. Universul Juridic, Supliment, pp. 24-27 (Retrieved from http://revista.universuljuridic.ro/supliment/european-regulation-veterinary-sanitaryfood-safety-area-component-european-policies-safety-food-products-protectionconsumer-interests-2007-retrospective-part-2/).

Chartered Institute of Environmental Health. (2019). Reference to EFSA removed in Brexit law transfer. Retrieved from https://www.cieh.org/food-safetyintegrity/2019/march/reference-to-efsa-removed-in-brexit-law-transfer/ 
482

483

484

485

486

487

488

489

490

491

492

493

494

495

496

497

498

499

500

501

502

503

504

505

506

507

508

509

510

511

512

513

514

515

516

517

Cho, J. (2006). The mechanism of trust and distrust formation and their relational outcomes. J Retailing. 82(1), 25-35. https://doi.org/10.1016/j.jretai.2005.11.002

Cohen, J. (1988). Statistical power analysis for the behavioral sciences (2nd ed.). Lawrence Earlbaum Associates.

Coveney, J., Henderson, J., Mayer, S., Mamerow, L., Taylor, A., \& Ward, P. (2015).

Consumer Trust. In Albala K (Ed.), The SAGE Encyclopedia of Food Issues. (1st ed., pp. 282-5.). SAGE Publications Ltd.

de Jonge, J., van Trijp, J. C. M., van der Lans, I. A., Renes, R. J., \& Frewer, L. J. (2008). How trust in institutions and organizations builds general consumer confidence in the safety of food: A decomposition of effects. Appetite, 51(2), 311-317. https://doi.org/10.1016/j.appet.2008.03.008

Dietz, G., \& Den Hartog, D. N. (2006). Measuring trust inside organisations. Person Rev 35(5), 557-588. https://doi.org/10.1108/00483480610682299

Ding, Y., Veeman, M. M., \& Adamowicz, W. L. (2013). The influence of trust on consumer behavior: An application to recurring food risks in Canada. Int J Econ Behav Organ. 92, 214-223. https://doi.org/10.1016/j.jebo.2013.06.009

Dolgopolova, I., Teuber, R., \& Bruschi, V. (2015). Consumers' perceptions of functional foods: Trust and food-neophobia in a cross-cultural context. Int I Consum Stud, 39(6), 708-715. https://doi.org/10.1111/ijcs. 12184

Duffy, R., Fearne, A., \& Healing, V. (2005). Reconnection in the UK food chain: Bridging the communication gap between food producers and consumers. $\mathrm{Br}$ Food J, 107(1), 17-33. https://doi.org/10.1108/00070700510573177

Edelman. (2018). 2018 Edelman Trust Barometer: Global Report.

Ekici, A. (2004). Consumer Trust and Distrust in the Food System: Some Implications for the Debates on Food Biotechnologies. Adv Consum Res, 31, 555-564.

Elliott, C. (2014). Elliott Review into the Integrity and Assurance of Food Supply Networks. In A National Food Crime Prevention Framework (Issue July). https://doi.org/10.1136/bmj.1.4348.621-a

Ervasti, H., Kouvo, A., \& Venetoklis, T. (2019). Social and Institutional Trust in Times of Crisis: Greece, 2002-2011. Soc Indicat Res, 141(3), 1207-1231. https://doi.org/10.1007/s11205-018-1862-y

Etienne, J., Chirico, S., McEntaggart, K., Papoutsis, S., \& Millstone, E. (2018). EU Insights - Consumer perceptions of emerging risks in the food chain. EFSA Supporting Publications, 15(4). https://doi.org/10.2903/sp.efsa.2018.EN-1394

European Commission. (2012). Special Eurobarometer 389: Europeans'attitudes towards food security, food quality and the countryside. 
518

519

520

521

522

523

524

525

526

527

528

529

530

531

532

533

534

535

536

537

538

539

540

541

542

543

544

545

546

547

548

549

550

551

552

553

554

European Food Safety Authority. (2010). Special Eurobarometer 354: Food-related risks.

Faul, F., Erdfelder, E., Lang, A.-G., \& Buchner, A. (2007). G*Power: A flexible statistical power analysis program for the social, behavioral, and biomedical sciences. Behav Res Meth, 39(2), 175-191. https://doi.org/10.3758/BF03193146

Finnish Food Safety Authority. (2018). Food Safety in Finland 2017.

Flexner, S. B., \& Hauck, L. C. (1993). Random House unabridged dictionary. New York: Random House.

Fritz, M., \& Fischer, C. (2007). The role of trust in European food chains: Theory and empirical findings. International Food and Agribusiness Management Review, 10(2), 141-161.

Halkier, B., Holm, L., Domingues, M., Magaudda, P., Nielsen, A., \& Terragni, L. (2007). Trusting, complex, quality conscious or unprotected?: Constructing the food consumer in different European national contexts. J Consum Cult, 73), 379-402. https://doi.org/10.1177/1469540507081629

Harrison McKnight, D., \& Chervany, N. L. (2001). Trust and Distrust Definitions: One Bite at a Time. In Review of Educational Research (Vol. 70, Issue 4, pp. 27-54). https://doi.org/10.1007/3-540-45547-7_3

Harrison McKnight, D., Choudhury, V., \& Kacmar, C. (2002). The impact of initial consumer trust on intentions to transact with a web site: a trust building model. J Strat Inform Syst, 11(3-4), 297-323. https://doi.org/10.1016/S09638687(02)00020-3

Hong, I. B., \& Cha, H. S. (2013). The mediating role of consumer trust in an online merchant in predicting purchase intention. Int $\mathrm{J}$ Inform Manag https://doi.org/10.1016/j.jijnfomgt.2013.08.007

Hong, I. B., \& Cho, H. (2011). The impact of consumer trust on attitudinal loyalty and purchase intentions in B2C e-marketplaces: Intermediary trust vs. seller trust. Int $J$ Inform Manag, 31(5), 469-479 https://doi.org/10.1016/j.ijinfomgt.2011.02.001

Houghton, J., van Kleef, E., Rowe, G., \& Frewer, L. (2006). Consumer perceptions of the effectiveness of food risk management practices: A cross-cultural study. Health, Risk and Society, 8(2), 165-183. https://doi.org/10.1080/13698570600677373

Järvelä, K., Mäkelä, J., \& Piiroinen, S. (2006). Consumers' everyday food choice strategies in Finland. Int J Consum Stud 30(4), 309-317. https://doi.org/10.1111/j.1470-6431.2006.00516.x

Kehagia, O., Linardakis, M., \& Chryssochoidis, G. (2007). Beef traceability: Are Greek consumers willing to pay? EuroMed Journal of Business, 2(2), 173-190. 
Kendall, H., Clark, B., Rhymer, C., Kuznesof, S., Hajslova, J., Tomaniova, M., Brereton, P., \& Frewer, L. (2019). A systematic review of consumer perceptions of food fraud and authenticity: A European perspective. Trends in Food Science and Technology, 94, 79-90. https://doi.org/10.1016/j.tifs.2019.10.005

Kjærnes, U. (2006). Trust and distrust: Cognitive decisions or social relations? J Risk Res, 9(8), 911-932. https://doi.org/10.1080/13669870601065577

Krockow, E. M., Takezawa, M., Pulford, B. D., Colman, A. M., \& Kita, T. (2017). Cooperation and trust in Japanese and British samples: Evidence from incomplete information games. International Perspectives in Psychology: Research, Practice, Consultation, 6(4), 227-245. https://doi.org/10.1037/ipp0000074

Li, T., \& Fung, H. H. (2013). Age differences in trust: An investigation across 38 countries. J Gerontol B Psychol Sci Soc Sci, 68(3), 347-355. https://doi.org/10.1093/geronb/gbs072

Lobb, A. E., Mazzocchi, M., \& Traill, W. B. (2007). Modelling risk perception and trust in food safety information within the theory of planned behaviour. Food Quality and Preference, 18(2), 384-395. https://doi.org/10.1016/j.foodqual.2006.04.004

Matthews, A. (2016). The Potential Implications of a Brexit for Future EU Agri-food Policies. EuroChoices, 15(2), 17-23. https://doi.org/10.1111/1746-692X.12128

Mayer, R. C., Davis, J. H., \& Schoorman, F. D. (1995). An Integrative Model Of Organizational Trust. Acad Manag Rev, 20(3), 709-734. https://doi.org/10.5465/amr.1995.9508080335

National Beef Association (UK). (2015). Beef Statistics. https://www.nationalbeefassociation.com/resources/beef-statistics/

Nuutila, J., \& Kurppa, S. (2017). Reaching goals for organic food in Finland: which changes should occur in the food chain? Organic Agriculture, 73), 303-314. https://doi.org/10.1007/s13165-016-0158-2

Peters, H. P., Lang, J. T., Sawicka, M., \& Hallman, W. K. (2007). Culture and technological innovation: Impact of institutional trust and appreciation of nature on attitudes towards food biotechnology in the USA and Germany. In Int J Publ Opin Res, 19(2), 191-220. https://doi.org/10.1093/ijpor/edm004

Poppe, C., \& Kjærnes, U. (2003). Trust in Food in Europe. A Comparative Analysis. Professional Report No.5 (Issue 5).

Rieger, J., Kuhlgatz, C., \& Anders, S. (2016). Food scandals, media attention and habit persistence among desensitised meat consumers. Food Pol, 64, 82-92. https://doi.org/10.1016/j.foodpol.2016.09.005 
592

593

594

595

596

597

598

599

600

601

602

603

604

605

606

607

608

609

610

611

612

613

614

615

616

617

618

619

620

621

622

623

624

625

626

627

628

629

Siegrist, M., Gutscher, H., \& Earle, T. C. (2005). Perception of risk: The influence of general trust, and general confidence. J Risk Res, 8(2), 145-156. https://doi.org/10.1080/1366987032000105315

Smith, A. P., Young, J. A., \& Gibson, J. (2007). How now, mad-cow? Consumer confidence and source credibility during the 1996 BSE scare. Eur J Market, 33(11/12), 1107-1122. https://doi.org/10.1108/03090569910292294

Stefani, G., Cavicchi, A., Romano, D., \& Lobb, A. E. (2008). Determinants of intention to purchase chicken in Italy: the role of consumer risk perception and trust in different information sources. Agribusiness, 24(4), 523-537. https://doi.org/10.1002/agr.20177

Tonkin, E., Wilson, A. M., Coveney, J., Webb, T., \& Meyer, S. B. (2015). Trust in and through labelling - a systematic review and critique. Br Food J, 117(1), 318-338. https://doi.org/10.1108/BFJ-07-2014-0244

Tse, Y. K., Zhang, M., Doherty, B., Chappell, P., \& Garnett, P. (2016). Insight from the horsemeat scandal Exploring the consumers' opinion of tweets toward Tesco. Industrial Management and Data Systems, 116(6), 1178-1200. https://doi.org/10.1108/IMDS-10-2015-0417

Van Kleef, E., Houghton, J. R., Krystallis, A., Pfenning, U., Rowe, G., Van Dijk, H., Van Der Lans, I. A., \& Frewer, L. J. (2007). Consumer evaluations of food risk management quality in Europe. Risk Anal, 27(6), 1565-1580. https://doi.org/10.1111/j.1539-6924.2007.00989.x

Vandenbroucke, J. P., von Elm, E., Altman, D. G., Gøtzsche, P. C., Mulrow, C. D., Pocock, S. J., Poole, C., Schlesselman, J. J., \& Egger, M. (2014). Strengthening the Reporting of Observational Studies in Epidemiology (STROBE): Explanation and elaboration. International Journal of Surgery, 12(12), 1500-1524. https://doi.org/10.1016/j.ijsu.2014.07.014

Wales, C., Harvey, M., \& Warde, A. (2006). Recuperating from BSE: the shifting UK institutional basis for trust in food. Appetite. 47(2), 187-195. https://doi.org/10.1016/j.appet.2006.05.007

Wideback, A. (2011). Finland Food and Agricultural Import Regulations and Standards - Narrative. https://gain.fas.usda.gov/Recent GAIN Publications/Food and Agricultural Import Regulations and Standards - Narrative_The Hague_Finland_12-13-2011.pdf Accessed 13 March 2020.

Wiseman, A. W., \& Popov, N. (Eds.). (2015). Comparative Sciences: Interdisciplinary Approaches (p. iii). Emerald Group Publishing. https://doi.org/10.1108/S1479367920140000026021

Yamagishi, T., \& Yamagishi, M. (1994). Trust and commitment in the United States and Japan. Motiv Emot, 18(2), 129-166. https://doi.org/10.1007/BF02249397 
630

631

632

633

634

635

636

637

638

639

640 Tables 


\begin{tabular}{|c|c|c|c|c|c|}
\hline Characteristic/country & Finland & Germany & Greece & UK & Total n (\%) \\
\hline & 253 (100\%) & 257 (100\%) & $261(100 \%)$ & $256(100 \%)$ & 1027 (100\%) \\
\hline \multicolumn{6}{|l|}{ Gender } \\
\hline Male & 119 (47\%) & 117 (46\%) & $121(46 \%)$ & 126 (49\%) & 483 (49\%) \\
\hline Female & 133 (53\%) & 139 (54\%) & 140 (54\%) & 129 (50\%) & $541(51 \%)$ \\
\hline Other & $1(0 \%)$ & $1(0 \%)$ & $0(0 \%)$ & $1(0 \%)$ & $3(0 \%)$ \\
\hline \multicolumn{6}{|l|}{ Age } \\
\hline $18-24$ & $34(13 \%)$ & 27 (11\%) & $31(12 \%)$ & $30(12 \%)$ & $122(12 \%)$ \\
\hline $25-34$ & $39(15 \%)$ & 39 (15\%) & $56(22 \%)$ & 40 (16\%) & $174(17 \%)$ \\
\hline $35-44$ & $46(18 \%)$ & $40(16 \%)$ & $55(21 \%)$ & 36 (14\%) & 177 (17\%) \\
\hline $45-54$ & 38 (15\%) & $45(18 \%)$ & 47 (18\%) & $46(18 \%$ & $176(17 \%)$ \\
\hline $55-64$ & $26(10 \%)$ & $36(14 \%)$ & $42(16 \%)$ & 39 (15\%) & $143(14 \%)$ \\
\hline $65+$ & $70(28 \%)$ & $70(27 \%)$ & 30 (12\%) & $65(25 \%)$ & 235 (23\%) \\
\hline \multicolumn{6}{|l|}{ Highest level of completed education } \\
\hline $\begin{array}{l}\text { Primary school or incomplete secondary } \\
\text { education }\end{array}$ & $27(11 \%)$ & $15(6 \%)$ & $3(1 \%)$ & $14(6 \%)$ & $59(6 \%)$ \\
\hline $\begin{array}{l}\text { Completed secondary education (GCSE/10 th } \\
\text { Grade USA) }\end{array}$ & 103 (41\%) & $43(17 \%)$ & $47(18 \%)$ & $42(16 \%)$ & 235 (23\%) \\
\hline $\begin{array}{l}\text { A-Level/High School Diploma or vocational } \\
\text { qualification }\end{array}$ & $53(21 \%)$ & $142(55 \%)$ & $52(20 \%)$ & 100 (39\%) & 347 (34\%) \\
\hline Undergraduate degree & $28(11 \%)$ & $16(6 \%)$ & 101 (29\%) & $65(25 \%)$ & $210(20 \%)$ \\
\hline Postgraduate degree or doctorate & $31(12 \%)$ & $41(16 \%)$ & $56(22 \%)$ & 35 (14\%) & $163(16 \%)$ \\
\hline Prefer not to answer & $11(4 \%)$ & $0(0 \%)$ & $2(1 \%)$ & $0(0 \%)$ & $13(1 \%)$ \\
\hline \multicolumn{6}{|l|}{ Marital status } \\
\hline Married or living with partner & $127(50 \%)$ & $154(60 \%)$ & $161(62 \%)$ & $148(58 \%)$ & $590(57 \%)$ \\
\hline Never married & 77 (30\%) & $56(22 \%)$ & $65(25 \%)$ & $64(25 \%)$ & $262(26 \%)$ \\
\hline
\end{tabular}


Separated/widowed/divorced

Prefer not to answer

* Percentages may not total $100 \%$ due to rounding

$\begin{array}{ccccc}44(17 \%) & 44(17 \%) & 29(11 \%) & 41(16 \%) & 158(15 \%) \\ 5(2 \%) & 3(1 \%) & 6(2 \%) & 3(1 \%) & 17(2 \%)\end{array}$

$3(1 \%)$

$6(2 \%)$

$3(1 \%)$

17 (2\%)

643

Table 2: Differences in levels of trust, distrust, risk perception and information sources between Finland, Germany, Greece and the UK measured using the Trust Toolkit (Benson et al., 2020)

\begin{tabular}{|c|c|c|c|c|c|c|c|}
\hline & & $\begin{array}{l}\text { Overall sample } \\
\qquad(\mathrm{n}=1027)\end{array}$ & & $\begin{array}{l}\text { Finland } \\
(\mathrm{n}=253)\end{array}$ & $\begin{array}{l}\text { Germany } \\
(\mathrm{n}=257)\end{array}$ & $\begin{array}{l}\text { Greece } \\
(n=261)\end{array}$ & $\begin{array}{c}\text { UK } \\
(n=256)\end{array}$ \\
\hline & Mean (SD) & $\mathrm{F}(\mathrm{df})$ & $\mathrm{p}$ & Mean (SD) & Mean (SD) & Mean (SD) & Mean (SD) \\
\hline General Trust & $4.253(1.188)$ & $56.233(3,1023)$ & $<0.001$ & $4.751(1.013)^{\mathrm{a}}$ & $4.179(1.134)^{b}$ & $3.572(1.129)^{c}$ & $4.531(1.128)^{\mathrm{a}}$ \\
\hline Chain Trust & 4.434 (1.177) & $20.413(3,1023)$ & $<0.001$ & $4.539(1.148)^{\mathrm{a}}$ & $4.061(1.172)^{b}$ & $4.082(1.118)^{\mathrm{b}}$ & $4.698(1.140)^{\mathrm{a}}$ \\
\hline Organisational Trust & $4.263(1.129)$ & $6.417(3,1023)$ & $<0.001$ & $4.315(1.144)^{\mathrm{a}}$ & $4.005(1.119)^{b}$ & $4.329(1.065)^{\mathrm{a}}$ & $4.405(1.151)^{a}$ \\
\hline Product Trust & $3.981(1.353)$ & $15.568(3,1023)$ & $<0.001$ & $4.227(1.321)^{\mathrm{a}}$ & $3.741(1.379)^{b}$ & $3.666(1.231)^{\mathrm{b}}$ & $4.300(1.364)^{a}$ \\
\hline Organisational Distrust & $4.321(1.100)$ & $16.701(3,1023)$ & $<0.001$ & $4.733(1.137)^{\mathrm{a}}$ & $4.191(1.112)^{b}$ & $4.227(1.001)^{\mathrm{b}}$ & $4.139^{\mathrm{a}}(1.049)^{\mathrm{b}}$ \\
\hline General Distrust & $3.497(1.251)$ & $92.744(3,1023)$ & $<0.001$ & $4.403(1.159)^{\text {a }}$ & $3.269(1.090)^{b}$ & $2.813(0.985)^{c}$ & 3.527 a $(1.209)^{d}$ \\
\hline Risk Perception ${ }^{1}$ & $3.616(0.747)$ & $44.113(3,1023)$ & $<0.001$ & $3.377(0.703)^{\mathrm{a}}$ & $3.523(0.659)^{\mathrm{a}}$ & $4.037(0.689)^{\mathrm{b}}$ & $3.516(0.761)^{\mathrm{a}}$ \\
\hline $\begin{array}{c}\text { Information Sources } \\
\text { sought }\end{array}$ & $3.56(2.02)$ & $3.035(3,1023)$ & 0.028 & $3.57(1.98)^{a}$ & $3.26(1.96)^{b}$ & $3.65(2.00)^{a}$ & $3.77(2.10)^{a}$ \\
\hline
\end{tabular}

646 Mean scores with different letters are significantly different between the countries (Bonferroni's test, $p<0.05)$.

${ }^{1}$ On a 5 point scale 
647 Table 3: Correlations between the trust measurement factors which contribute to Product Trust (EU beef burgers).

648 (Pearson's R)

\begin{tabular}{l|ccc}
\hline Model & 1 & 2 & 3 \\
\hline Product Trust & - & & \\
Chain Trust & $.561^{\star *}$ & - & - \\
Org Trust & $.499^{\star *}$ & $.446^{\star *}$ & $.321^{\star *}$ \\
General Trust & $.321^{\star *}$ & $.364^{\star *}$ & \\
\hline
\end{tabular}

649 *. Correlation is significant at the 0.05 Level (2-Tailed)

$650 * *$. Correlation is significant at the 0.01 Level (2-Tailed)

651

652

653

654

655

656

657

658

659

660

661 
Table 4: Hierarchical multiple regression predicting Product Trust (EU beef burgers).

\begin{tabular}{|c|c|c|c|c|c|}
\hline Prediction & Product Trust & Model 1 & & Model 2 & \\
\hline \multirow{4}{*}{ Sociodemographic } & Variables & B (SE) & $\beta$ & $\mathrm{B}(\mathrm{SE})$ & $\beta$ \\
\hline & & & & & \\
\hline & Age & $-1.136(0.255)$ & $-.143^{* *}$ & $-1.252(0.201)$ & $-.158^{\star *}$ \\
\hline & Sex & $-2.071(0.861)$ & $-.077^{\star}$ & $-2.505(0.663)$ & $-.094^{* *}$ \\
\hline \multirow[t]{3}{*}{ Trust Factors } & Organisational & - & - & $.202(0.019)$ & $.286^{\star *}$ \\
\hline & Org. Distrust & - & - & $.182(0.104)$ & .044 \\
\hline & Gen. Distrust & - & - & $.177(0.077)$ & $.065^{\star}$ \\
\hline $\boldsymbol{F}$ & $10.677^{\star \star}$ & & & $107.921^{* *}$ & \\
\hline Adjusted $R^{2}$ & $0.019 * *$ & & & $0.422^{* *}$ & \\
\hline
\end{tabular}


667 Figure

668 Figure 1 Differences in Trust and Distrust factors in Finland, Germany, Greece and the UK

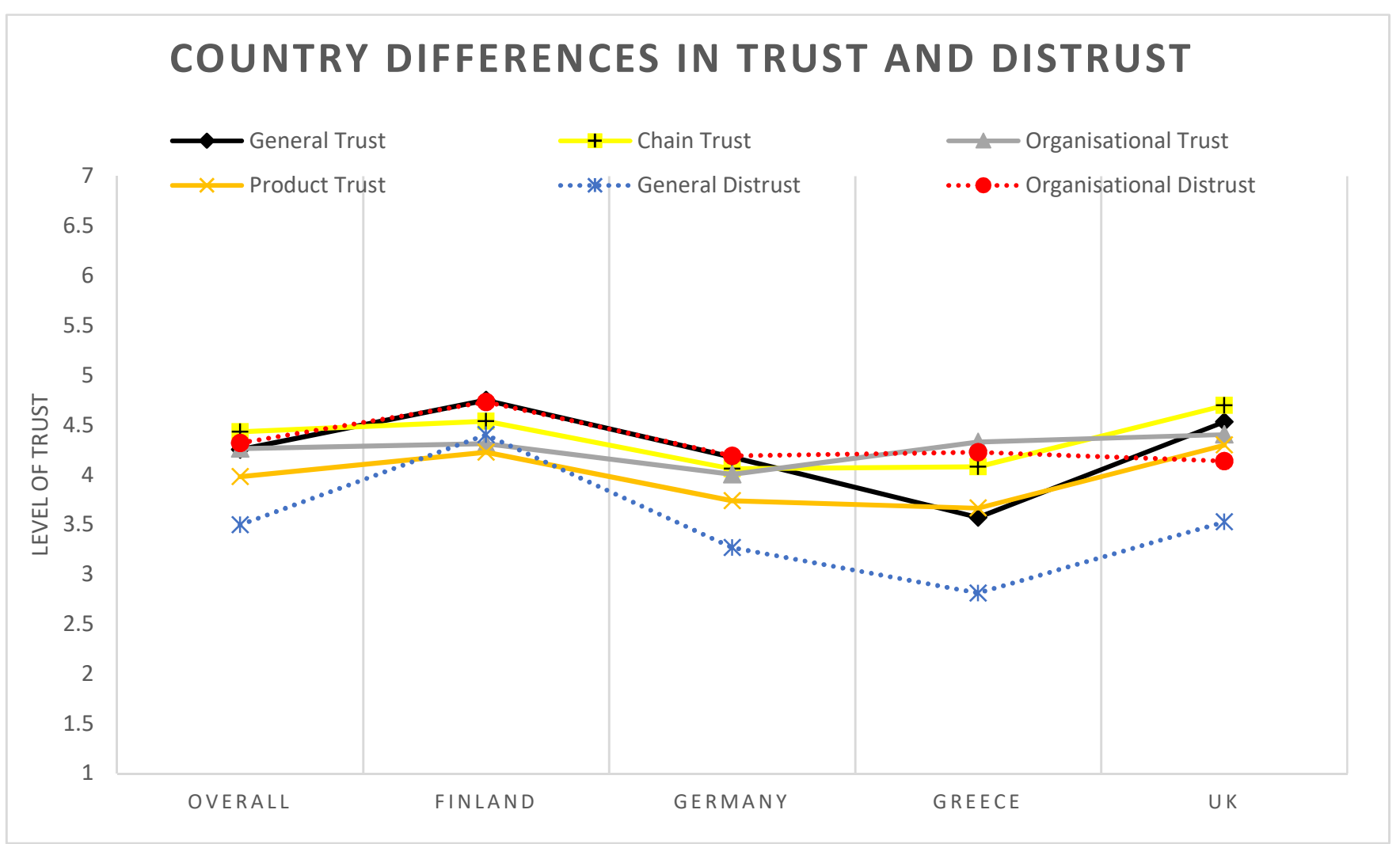


669

Credit Author Statement

670

671 Blain Murphy: Writing- Original draft preparation, Investigation, Formal Analysis

672 Tony Benson: Conceptualization, Methodology, Investigation, Formal Analysis,

673 Writing-Reviewing and Editing

674 Fiona Lavelle: Conceptualization, Methodology, Writing- Reviewing and Editing.

675 Christopher T. Elliott: Writing- Reviewing and Editing, Funding Acquisition

676 Moira Dean: Conceptualization, Supervision, Writing- Reviewing and Editing,

677 Funding Acquisition

678 